\title{
ДО ІСТОРІЇ ФЕОХРОМОЦИТОМИ
}

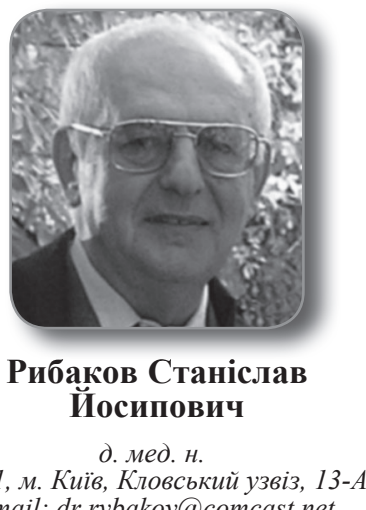

01021, м. Київ, Кловський узвіз, 13-

e-mail:dr.rybakov@comcast.net

\author{
С.Й. Рибаков
}

Асоціація ендокринних хірургів України, м. Київ
Феохромоцитома - катехоламін-продукуюча пухлина хромафінної тканини - $\epsilon$ однією 3 найзагрозливіших і найзагадковіших форм ендокринної патології. Незважаючи на значні успіхи у вивченні цих пухлин, дослідження їх молекулярно-генетичних особливостей та вражаючі можливості виявлення мінімальних за розмірами новоутворень, феохромоцитома дуже часто залишається діагностичною загадкою та дебютує виключно тяжкою клінічною картиною, що вимагає великих зусиль для врятування життя хворого, а інколи вона виявляється трагічною знахідкою на автопсії. 3 притаманною французам дотепністю J. de Courcey (1952) [1] назвав феохромоцитому «великим імітатором» через наявність численних клінічних «масок» захворювання, безліч синдромів і симптомів (понад 80) та не меншу кількість взагалі безсимптомних випадків. іiї ще називали «фармакологічною бомбою», «імпресіоністською пухлиною» через вкрай мінливий, а інколи бурхливий характер перебігу, пов'язаний із неконтрольованою надмірною гормональною секрецією [2]. «Метаболічним вулканом» охрестив феохромоцитому R. Robinson (1980) [3] за її здатність до нерідко безсимптомного перебігу та раптові вибухові клінічні прояви, що часто закінчувалися смертю хворих.

Документована історія феохромоцитоми починається з 1886 року, коли німецький патолог Felix Frankel [4] повідомив про 18-річну хвору на ім'я Minna Roll, яка виявилася носієм цієї пухлини. İ̈̈ історія була досить короткою та трагічною. Протягом року вона страждала від нападів, що супроводжувалися відчуттям страху, тремором, головним болем, нудотою, блюванням, закрепами. На час прибуття до клініки стан її був тяжким, пульс частим, напруженим, шкіра - блідою (артеріальний тиск у той час ще не вимірювали). У неї виявили зоб, ретинопатію. Наступними днями спостерігалися підвищення температури, задишка, біль у грудній клітці, пітливість. На дев'яту добу хвора померла, як вважали, від судинної недостатності. На автопсії знайшли пухлини обох надниркових залоз: «одну розміром з кулак, другу - трохи меншу». Пухлини були хромафінопозитивними, багато васкуляризованими, складалися 3 великих веретеноподібних клітин і були розцінені як медулярна ангіосаркома. У нирках були ознаки паренхіматозного нефриту, потовщення стінок судин. Серце було гіпертрофованим. Зоб не описувався. F. Frankel вважав, що всю патологію зумовлено нефритом, а надниркові пухлини були безсимптомними (латентними) через відсутність ознак хвороби Аддісона.

Декілька випадків подібних пухлин, що вважалися медулярними, під різними назвами описано наступними роками [5, 6], а 1896 року P. Manasse [7] продемонстрував їх здатність набувати брунатного відтінку під дією солей хрому, звідки пішов термін «хромафінна» тканина. Паралельно з'явилися відомості про пухлини з аналогічними властивостями, але розташовані у заочеревинному просторі поза наднирковими залозами. Вони отримали назву парагангліом [8]. Лише 1912 року L. Pick [9] запропонував для визначення цих типів пухлин термін «феохромоцитома». Слід відзначити, що здатність феохромоцитоми до гормональної секреції та роль останньої у розвитку клінічної картини захворювання було з'ясовано значно пізніше. Гіпотетично цю думку висловили 1922 року M. Labbe et al. [10], які пов'язали синдром пароксизмальної артеріальної гіпертензії у 28-річної жінки із феохромоцитомою, яку знайшли у неї на автопсії. Перші декілька операцій з приводу феохромоцитоми було зроблено без попередньо встановленого діагнозу. 


\section{ЛЕКЦії}

E. Villard 1923 року [11] видалив «злоякісну надниркову парагангліому», але пацієнт помер від шоку.

Лише три роки по тому, 1926 року, з невеликим інтервалом було успішно виконано перші операції 3 приводу феохромоцитоми. Найпершу було зроблено C. Roux та описано в дисертації R. Muchl (1928) [12], присвяченій «наднирковим парагангліомам». C. Roux, видатний швейцарський хірург, учень T. Кохера спостерігав пацієнтку S., жінку 33 років, яка протягомі 2 років страждала від нападів нудоти та запаморочення. Можливо, це були гіпертензивні кризи, але в дисертації про це не згадується. Пальпаторно у правому підребер'ї у хворої визначалося утворення розміром 3 апельсин. За результатами рентгенологічного дослідження припустили наявність первинної пухлини печінки. 25.02.1926 р. C. Roux із лапаротомного доступу видалив пухлину розміром 13 см, що походила з правої надниркової залози та виявилася доброякісною феохромоцитомою. Хвора одужала. Друга хвора, монашка мати Joachim зі штату Онтаріо, поступила в клініку Мейо (США) 3 приводу частих нападів артеріальної гіпертензії протягом 18 місяців, які супроводжувалися підвищенням тиску до 320 мм рт. ст. і характерними супутніми симптомами. Причинами кризів вважали подразнення симпатичного ланцюжка та планували виконання шийної симпатектомії. Керівник клініки Ch. Мауо (1927) [13] припускав, що провокуючі кризи токсини виділяються періодично через подразнення симпатичних нервів, і планував спочатку зробити шийну симпатектомію. Але через те, що напади супроводжувалися болем у попереку, було визнано доцільним втручання на поперековому відділі симпатичного ланцюга. 9.10.1926 р. він виконав лапаротомію та позаду хвоста підшлункової залози знайшов і видалив пухлину $6 \times 4$ см, що походила з лівої надниркової залози. За результатами гістологічного дослідження вона виявилася доброякісною феохромоцитомою. Напади припинилися. Хвора одужала, перебувала під спостереженням впродовж 18 років і померла від коронарного тромбозу. Того ж 1926 року H. Vaquez та E. Donzelot [14] прижиттєво діагностували феохромоцитому, але не змогли локалізувати пухлину. Хворому було призначено рентгенівське опромінення зони ії можливого розташування, після чого спостерігалася ремісія протягом 6 місяців. Далі розвинувся рецидив. Хворий помер. Наявність феохромоцитоми підтверджено на автопсії. Невдовзі М. Pincoff (1928) [15] також прижиттєво діагностував феохромоцитому, але не зміг ії локалізувати. Успішнішим виявився A. Shipley (1929) [16], який, встановивши діагноз, зробив експлорацію лівої половини заочеревинного простору, не знайшов пухлини, а через 2 тижні під час другої операції видалив ії з правого боку. Але це все були поодинокі казуїстичні випадки, які не давали уявлення про сутність патології.

До середини 30-х рр. минулого сторіччя в літературі описано близько 60 випадків феохромоцитоми, більшість з яких були знайденими на автопсії [17]. Вони траплялися однаково часто у жінок і чоловіків; поодинокі - у дітей. У понад $80 \%$ хворих спостерігалася артеріальна гіпертензія, не завжди пароксизмальна. Пухлини досягали ваги від кількох грамів до 1 кг. Траплялися новоутворення зі злоякісними властивостями, але метастази фіксували вкрай зрідка. Були відомі поєднання феохромоцитоми з нейрофіброматозом (хвороба Реклінгаузена). Небагато патологів мали достатній досвід щодо цих пухлин, і тому значна кількість їх ідентифікувалися помилково.

Впродовж першої половини XX сторіччя історію відкриття та вивчення основних гормонів, що виробляються хромафінною тканиною - адреналіну та норадреналіну, прикрашають імена багатьох дослідників. Серед них слід згадати G. Oliver, E. Schaefer, D. Abel, J. Takamine, T. Oldrich, O. Fuert, L. Szymanowicz, N. Cybulski, U. von Euler та ін. У зв'язку з тим, що певні групи вчених працювали окремо, інколи одночасно або з невеликим часовим інтервалом траплялося, що одне й те саме відкриття робилось кількома дослідниками; це часто ставало підгрунтям для інтриг і взаємних звинувачень [18]. Щодо феохромоцитоми окремі дослідники припускали, що ця пухлина продукує певну пресорну субстанцію, можливо, адреналін, який зумовлює розвиток клінічних проявів захворювання. C. Rabin 1929 року [19] підтвердив наявність у феохромоцитомі в надмірній кількості цієї субстанції, яка визначалася і в нормальній хроматофінній тканині. До речі, ії знаходили в екстрактах із пухлин і раніше, але не давали чіткого пояснення [17]. Цього ж року було отримано 60 мг адреналіну з пухлини [19], а 1935 року A. Kendall видобув 120 мг кристалічного адреналіну [20]. Адреналін у високій кількості було знайдено у крові хворого під час кризу артеріальної гіпертензії, та він зник після видалення пухлини та припинення кризів [21]. Слід відзначити, що визначення адреналіну було здійснено за допомогою біологічного методу, і лише за 2 роки було розроблено хімічний кількісний метод та остаточно підтверджено роль адреналіну в розвитку клініки 


\section{ЛЕКЦії}

феохромоцитоми [22]. Несподівану смерть хворих із феохромоцитомою пов'язували 3 надлишком викиду адреналіну [23], а поопераційний шок - із наднирковою недостатністю [24].

Норадреналін, хоча і був синтезований ще на початку століття, довго не привертав до себе уваги в аспекті зв'язку з феохромоцитомою. P. Holton 1949 року [25] вперше продемонстрував наявність норадреналіну у феохромоцитомі. Особливу цінність мали дослідження секреції, метаболізму, методів визначення катехоламінів та їх діагностичного значення, проведені 50-ми роками U. von Euler et al. і викладені майже у 20 їх публікаціях $[26,27]$. Зокрема, вони показали наявність великих кількостей адреналіну, норадреналіну, допаміну (попередник норадреналіну) в організмі хворих із цими пухлинами та підвищену екскрецію їх із сечею. Не менше значення мала серія праць A. Lund [28], понад 10, присвячених дослідженню вмісту катехоламінів у крові. Ці праці відіграли значну роль у розробці методів діагностики феохромоцитоми. Визначення катехоламінів та їх метаболітів у крові та сечі до теперішнього часу залишається основним діагностичним тестом для феохромоцитоми [29-31].

Діагноз феохромоцитоми, незважаючи на можливості клінічних і біохімічних досліджень, залишався складним через брак ефективних методів візуалізації надниркових залоз.

Мало допомагали рентгенологічні методи, зокрема оглядова рентгенографія заочеревинного простору, томографія, екскреторна пієлографія. Газовоконтрастні рентгенологічні методики (пневморетроперитонеографія, пневмоперинефрос), хоча й трохи ефективніші, були небезпечними через інвазійний характер і нерідко викликали тяжкі кризи гіпертензії та інші ускладнення [21]. Тим не менше, на кінець 30-х рр. було виконано додатково ще понад 20 операцій із приводу феохромоцитоми [21, 32], включаючи 3 у клініці Мейо [20] і 2, зроблені у Чикаго [33]. Хірурги звернули увагу на характерну рису клініки феохромоцитоми - різке підвищення артеріального тиску під час пальпації пухлини у ході операції та різке зниження після їі видалення [33]. Вперше було описано випадки феохромоцитоми із синдромом постійної артеріальної гіпертензії [34]. Наступними роками було опубліковано кілька збірних статистик із характеристиками пухлин хромафінної тканини. Зокрема, R. Mackeith (1944) [35] повідомив про 165 випадків феохромоцитоми, серед яких було 16 двобічних пухлин, 15 злоякісних і 13 екстраадреналових парагангліом. E. Calkins та J. Howard (1947) [36] зібрали відомості про 176 хворих; у 47 з них пухлини були гормонально активними та у 16 двобічними.

Впродовж 40-х років було запропоновано декілька функціональних тестів, що мали полегшити діагностику феохромоцитоми. Це були так звані провокаційні та адренолітичні проби. Перші за наявності феохромоцитоми викликали підвищення артеріального тиску або навіть виникнення кризів шляхом масажу (пальпації) зони локалізації пухлини (пальпаторна проба), різкого нахилення тіла (ортостатична проба), застосування низьких температур (холодова проба) або введення певних хімічних речовин (мехоліл, тетраетиламонію хлорид, адреналін). G. Roth та W. Kvale 1945 року [37] розробилипровокаційний гістаміновийтест.Досліджуючи можливість застосування гістаміну для попередження кризів під час операції з приводу феохромоцитоми, вони побачили, що препарат, навпаки, призводив до підвищення артеріального тиску. На підставі цього було створено пробу для діагностики феохромоцитоми, але вона знайшла застосування лише для пухлин із пароксизмальною гіпертензією на тлі нормального артеріального тиску та була небезпечною за постійно підвищеного тиску. Друга група тестів ґрунтувалася на здатності деяких хімічних сполук вибірково нормалізувати тиск у хворих із феохромоцитомою за рахунок зниження рівня або нейтралізації циркулючих у крові надмірних кількостей катехоламінів, тоді як він залишався незмінним за інших форм артеріальної гіпертонії. M. Goldenberg et al. 1947 року [38] показали, що введення адреноблокатора бензодіоксану супроводжувалося різким зниженням артеріального тиску у хворих із феохромоцитомою, але він залишався незмінним за ессенціальної гіпертонічної хвороби та в осіб із нормальним тиском. За допомогою цього тесту та рентгенографії наступного року E. Ganem та G. Cahill [39] успішно діагностували та видалили дві феохромоцитоми у 12-річної дівчинки. Це був перший випадок операції з приводу множинної пухлини хромафінної тканини. Більше поширення отримала адренолітична проба з фентоламіном (реджитином), що ії вперше використали L. Iseri at al. 1951 року [40]. Вона виявилася ефективним діагностичним засобом, крім того, цей препарат вдало застосовувався для припинення кризів артеріальної гіпертензії. В СРСР користувалися вітчизняним препаратом - тропафеном, який добре зарекомендував себе у діагностиці та лікуванні феохромоцитоми. 


\section{ЛЕКЦії}

Розвиток методів діагностики, повідомлення про успішні випадки хірургічних втручань, зростаюча кількість публікацій, присвячених феохромоцитомі, обумовили появу серії оглядових праць, які мали велике значення для формування сучасних уявлень про цю патологію, особливості її клінічних проявів, сприяли розробці тактикотехнічних підходів до лікування. В їх числі слід відзначити етапну роботу J. Graham «Pheochromocytoma and hypertension. An analysis of 207 cases» (1951) [41]. Автор виконав поглиблений аналіз великого клінічного матеріалу та зробив низку важливих узагальнюючих висновків. Згідно з цією збірною статистикою, 90\% пухлин локалізувалися в надниркових залозах, із незначним переважанням у правій. Решта (10\%) були у заочеревинному просторі попереду хребта, у зоні великих судин, тіла Цуккеркандля; два випадки (0,96\%) - у грудній клітці. Двобічні адреналові пухлини спостерігалися у $10 \%$ випадків, злоякісні - в 11\%. Доступними пальпації пухлини були у $13 \%$ випадків. Клінічна картина була вкрай варіативною, але більш-менш типовою, з варіантами пароксизмальної, постійної та змішаної гіпертензії. Оперовано було 125 хворих, 33 (26,4\%) з яких померли. У 2/3 випадків використовувався поперековий підхід до пухлини, в 1/3 - абдомінальний, у поодиноких - торакальний або комбінований. Оптимальним обсягом операції вважали тотальну адреналектомію з пухлиною. Для знеболювання користувалися газовим ефірно-кисневим наркозом. Під час операції велика увага зверталася на скорішу «блокаду» відтоку крові від пухлини шляхом затискання центральної вени надниркової залози, що забезпечувало профілактику підвищення артеріального тиску та розвиток кризу. Зростання артеріального тиску припиняли за допомогою деструкції черевного нерва, введення амілнітриту, пізніше - адреноблокаторів (фентоламін, реджитин, тропафен тощо). За гіпотензії після видалення пухлини переливали значні кількості крові, вводили адреналін. Було 4 (3,2\%) рецидиви.

Розширенню уявлень про феохромоцитому сприяли деякі додаткові епідеміологічні дослідження. Зокрема, колега J. Graham'a R. Smithwick у межах попереднього дослідження [41] повідомив про випадкове виявлення 8 (0,47\%) феохромоцитом під час 1700 операцій поперекової симпатектомії з приводу артеріальної гіпертензії. Вони встановили, що у США щорічно близько 800 осіб вмирають від цієї хвороби, що лікується. Автори разом зі співробітниками, крім статистичного матеріалу, використовували дані з власного досвіду, що включав спостереження 11 випадків феохромоцитоми та був представлений у низці публікацій. Більшість із цих узагальнених матеріалів наступними десятиріччями виявилися базовими у розробці лікувально-діагностичних підходів до пухлин хромафінної тканини.

Не менш значними були дослідження феохромоцитоми, проведені у клініці Мейо. За результатами скринінгу 7993 хворих з артеріальною гіпертензією, тут виявили 51 (0,63\%) феохромоцитому [42], але серед 15984 серійних автопсій було знайдено лише 15 (0,09\%) пухлин, тобто у 7 разів менше [43]. Клініка Мейо навела вражаючі результати діагностики та лікування вищезазначеної групи з 51 хворого з феохромоцитомою [42]. В усіх було встановлено передопераційний діагноз за допомогою вимірювання вмісту катехоламінів у крові, тестів із гістаміном або фентоламіном, оглядової рентгенографії з внутрішньовенною пієлографією. Як доступ використовували верхню поперечну лапаротомію. Оптимальним обсягом операції для однобічних пухлин вважали адреналектомію, для двобічних рекомендували за можливості зберігати частину коркової речовини. Поопераційної летальності не було.

На кінець 50-х рр. феохромоцитома стала ширше відомою. Було описано понад 600 випадків; багато з них успішно оперовані [44]. Але операції з приводу цих пухлин залишалися складними та небезпечними через негативні впливи гормонів на серцево-судину систему, надто на циркуляцію під час оперативних втручань, фізичних навантажень, пологів, інвазійних процедур. Було встановлено, що норадреналін вироблявся майже всіма пухлинами, адреналін - частиною, допамін - нечисленними, частіше злоякісними [27, 45]. Sh. Brunjes et al. 1960 року [46] висловили припущення, що вазоконстрикція, обумовлена дією катехоламінів на а-рецептори, $\epsilon$ причиною гіповолемії. Видалення пухлини (джерела катехоламінів) викликає гостре розширення судинного русла з наступною гіпотензією та поопераційним шоком. Іншими небезпечними чинниками були тахікардія та серцева аритмія, що стимулювалися катехоламінами шляхом гіперстимуляції $\beta$-рецепторів. Розробка та впровадження протягом 60-х рр. низки препаратів - блокаторів а- та $\beta$-рецепторів, дозволили забезпечити контроль негативних ефектів надмірної кількості катехоламінів у хворих із феохромоцитомою. Внаслідок цього операції стали безпечнішими, з меншою кількістю ускладнень ідобрими кінцевими результатами. 
Цікавою знахідкою стало відкриття родинних, спадкових форм феохромоцитоми. Перші повідомлення про знахідки пухлин хромафінної тканини у членів однієї родини з'явилися у середині 40-х рр. $[36,47]$. У подальшому кількість подібних спостережень зростала. Пухлини часто бували двобічними, екстраадреналовими, нерідко злоякісними. Так, в опублікованій 1962 року Р. Cushman [48] статистиці наведено відомості про 33 випадки родинних пухлин, серед яких 51\% були множинними, $15 \%$ - позанаднирковими, 3\% злоякісними. У 12 родинах із 19 дітей хворих батьків 10 були носіями феохромоцитоми: 6 з 11 синів і 4 з 8 дочок. Загалом частота родинних форм складала 8,7\% серед зібраних автором 380 феохромоцитом. J. Sipple 1961 року [49] на автопсії 33-річного чоловіка виявив незвичайну поєднану патологію феохромоцитому обох надниркових залоз, рак щитоподібної залози, який був пізніше ідентифікований як медулярний, i збільшення прищитоподібних залоз (можливо, аденоматозних). Подібну спільну патологію він зафіксував у 5 (0,93\%) з 537 хворих із феохромоцитомою. Слід відзначити, що майже на 30 років раніше, 1932 року, A. Eisenberg та H. Wallerstein [50] описали випадок співіснування феохромоцитоми та папілярного раку щитоподібної залози в одного пацієнта, а ще через 20 років таке ж повідомлення зробили J. DeCourcy та L. DeCourcy [1]. 3 часом з'явилися декілька аналогічних повідомлень. У них відзначалося, що патологія мала характер спадкової за автосомно-домінатним типом із високою пенетрантністю. Основними їі компонентами, крім феохромоцитоми (нерідко двобічної або екстраадреналової, чи злоякісної), були медулярний рак щитоподібної залози, гіперпаратиреоз (аденома або гіперпластичний варіант), характерні зміни фенотипу; перші дві складові були обов'язковими. A. Steiner at al. 1968 року [51] на підставі вивчення цієї патології застосувалидля неїназву «синдроммножинноїендокринної неоплазії 2-го типу (МЕН-2)», на відміну від синдрому MEH-1, раніше описаного P. Wermer (1954), до якого входили аденома прищитоподібної залози, аденома гіпофіза, нейроендокринна ентеропанкреатична пухлина, бронхіальний або ентеральний карциноїд, а також ще близько 20 видів ендокринних пухлин у різних поєднаннях. Наявність певних варіантів синдрому МЕH-2 стала підставою для виділення двох його підтипів - МЕН-2А та МЕН-2B [52]. До першого належали феохромоцитома, медулярний рак щитоподібної залози, гіперпаратиреоз, до другого - феохромоцитома, медулярний тиреоїдний рак, зміни фенотипу за типом синдрому Марфана та деякі кісткові, неврологічні, ентеральні порушення [53]. Наступними роками багатьма дослідниками розшифровано варіанти молекулярно-генетичних порушень, які призводять до розвитку цих спадкових синдромів, що дозволило значно поліпшити їх ранню діагностику, а отже результати лікування.

У зв'язку з наявністю в організмі людини скупчень хромафінних клітин не лише у мозковій речовині надниркових залоз вони, природно, можуть бути джерелом пухлинного росту 3 відповідною гормональною продукцією та клінікою. Подібні утворення локалізуються, зокрема, у зоні парагангліїв сплетінь симпатичної нервової системи (заочеревинного, торакального, шийного), у головному мозку, сечовому міхурі, каротидному тільці. Відносно походження, патогенезу, властивостей подібних пухлин існують різні погляди. Наприклад, клітини деяких пухлин не забарвлювалися солями хрому, що давало підстави окремим дослідникам не вважати їх хромафінними; інші ж, навпаки, не розглядали здатність до забарвлення обов'язковою умовою, але звертали увагу на гормональну функцію. Спільним для них $\epsilon$ загальне походження 3 ектодермальних клітин зародкового гребінця. Ці пухлини отримали декілька визначень: «екстраадреналові феохромоцитоми», «парагангліоми», «нейробластоми». Висвітлення цих питань не $\epsilon$ метою даного повідомлення. Можна лише згадати, що вказівка на наявність двох випадків пухлин у грудній клітці $€$ у згаданому вище огляді J. Graham [41]. I. Zimmerman at al. 1953 року [54] повідомили про феохромоцитому сечового міхура, наступними 30 роками було описано ще понад 100 подібних пухлин [55]. Норадреналінсекретуюча пухлина каротидного тіла вперше була описана G. Glenner et al. 1961 року [56].

Незважаючи на успіхи у хірургічному лікуванні феохромоцитоми, «вузьким місцем» залишалися питання вчасної діагностики. Понад третину пухлин, що знаходили, залишалися нерозпізнаними, i хворі нерідко раптово помирали після невеликих хірургічних втручань, під час пологів, інтенсивних фізичних вправ. Певною мірою була можливість підвищення ефективності діагностики шляхом скринінгу за допомогою дослідження катехоламінів у крові та сечі у певних категорій хворих: із пароксизмальною гіпертензією, стійким підвищенням артеріального тиску та резистентністю до антигіпертензивних засобів, із діабетом і гіпертонією, медулярним раком щитоподібної залози. 
Функціональні проби з гістаміном і реджитином поступово втрачали своє значення через обмеженість показань, можливі ускладнення та не завжди чіткі результати. Нові запропоновані тести 3 тираміном, глюкагоном не набагато поліпшили ситуацію [30, 57].

Розробка нових технологій для візуалізації надниркових залоз відіграла значну роль у поліпшенні діагностики феохромоцитоми. На заміну рентгенологічним, пневморентгенографічним, ангіографічним методам 70-80 роками прийшли ультразвукові, комп'ютерна, магнітнорезонансна позитронно-емісійна томографія, які були в змозі виявляти пухлини розміром до 2-3 мм як адреналової, так і екстраадреналової локалізації. Окремо слід згадати специфічні радіонуклідні методики діагностики за допомогою ${ }^{131}$ І-мета-йодобензилгуанідину (MIBG) [58]. Завдяки здатності до накопичення в клітинах, що виробляють катехоламіни, цей препарат виявився неоціненним не лише для виявлення пухлин у надниркових залозах, але й у будь-яких інших ділянках тіла, надто рецидивних пухлин і метастазів. Призначуваний за певними режимами, він застосовується для лікування злоякісних феохромоцитом і метастазів, що не підлягають оперативному лікуванню.

Період з початку 80-х рр. минулого сторіччя слід розглядати як значний прорив в ендокринній хірургії та, зокрема, у хірургії надниркових залоз. Перше, що має бути відзначеним, - це розробка та впровадження ендоскопічних методів операцій на надниркових залозах [59]. Ці втручання, що характеризуються малою травматичністю, незначною крововтратою, невисоким рівнем ускладнень, коротким реабілітаційним періодом, виявилися надто придатними для лікування пухлин хромафінної тканини. На теперішній час чимало провідних клінік володіють досвідом багатьох десятків і навіть сотень подібних операцій, у тому числі з приводу феохромоцитоми. Важливим науковим досягненням у цей час слід вважати результати вивчення молекулярно-генетичних властивостей пухлин хромафінної тканини. Було з'ясовано роль мутацій низки генів у походженні родинних феохромоцитом та у складі синдромів МЕH-2, зокрема RET, SDHD, SDHC, VHL тощо. 3 цих питань було опубліковано численні праці кількох груп дослідників - L. Mulligan, C. Eng, K. Pacak, G. Eisenhofer та ін.

Результати поглибленого вивчення патогенезу, клініки, варіантів перебігу феохромоцитоми, застосування прецизійних методів діагностики, включа- ючи використання тонких гормональних, молекулярно-генетичних досліджень, передових технологій візуалізації, операцій із високим рівнем технічної забезпеченості дають можливість наразі здійснювати ефективну діагностику та лікування феохромоцитоми з мінімальним рівнем ускладнень та летальності.

У вітчизняній літературі пухлину хромафінної тканини, знайдену на автопсії, вперше описано у дисертації М.І. Брюханова 1899 року [60]. Ще через 30 років патологи А.А. Крилов (1929) [61], В.І. Журавльова (1931) [62] теж повідомили про казуїстичні випадки пухлин хромафінної тканини, знайдені також на автопсії. Раніше, 1924 року, М.М. Анічков [63] охарактеризував різні варіанти феохромоцитоми в огляді, присвяченому пухлинам симпатичної нервової системи. Слід відзначити, що видатний український анатом В.А. Бец 1864 року [64] вперше описав хромафінну реакцію клітин мозкової речовини надниркових залоз, від чого пішло подальше вивчення цієї проблеми. Першу операцію в СРСР із приводу феохромоцитоми, діагноз якої успішно встановив терапевт, академік Г.Ф. Ланг, було виконано у травні 1940 року відомим хірургом, академіком С.І. Спасокукоцьким. Того ж року у жовтні другу подібну операцію зробив його учень, теж майбутній академік О.М. Бакулєв [цит. 65]. На жаль, подробиці про ці операції не збереглися. Місяцем пізніше, 28 листопада 1940 р. третю операцію з приводу феохромоцитоми було виконано у Всесоюзному інституті експериментальної ендокринології в Москві професором О.В. Ніколаєвим. Відомості про неї заслуговують на увагу [66]. Хворий К., чоловік, 38 років, протягом 8 років страждав від нападів головного болю, серцебиття, блювання, що супроводжувалися різким зблідненням шкіри. Лікувався без успіху з діагнозами гіпертиреоїдного зоба, міокардиту, набряків Квінке у Києві, Ленінграді, Харкові. Останнього разу у Вінниці професор Шкляр на підставі підвищення артеріального тиску до 240 мм рт. ст., вмісту глюкози у крові до 175 мг\% і лейкоцитозу до 22000 під час нападу встановив діагноз парагангліоми та направив хворого до Москви. В Інституті напади пароксизмальної гіпертензії до 290 мм рт. ст. тривалістю до 30 хвилин повторювалися 4-7 разів на добу та супроводжувалися гіперглікемією, підвищенням лейкоцитозу. За результатами обстеження (без визначення катехоламінів) діагноз було підтверджено, і 21.10.1940р. було зроблено лапаротомію, під час якої знайдено пухлину розміром з гусяче яйце, що походила 3 правої 
надниркової залози та була тісно зрощена з ниркою, печінкою, хребтом (пухлину не було видалено?). 28.11.1940 р. 3 правобічного люмбального доступу з резекцією 12-го ребра пухлину вагою 120 г було успішно видалено. Через 30 хвилин у хворого розвинувся тяжкий поопераційний шок, 3 якого його вдалося вивести через декілька годин із великими труднощами. Далі поопераційний період перебігав без ускладнень. Напади пароксизмальної гіпертензії припинилися. Патогістологічний висновок - феохромоцитома. Хімічним шляхом у пухлині було визначено великий вміст катехоламінів. Хворий спостерігався до початку війни, напади не повторювалися, артеріальний тиск залишався нормальним.

До середини 60-х рр. у вітчизняній літературі було опубліковано відомості про 150 випадків феохромоцитоми та 54 операції з приводу цієї патології [65]; до 1972 р. остання цифра збільшилася до 111 [67]. Про поширеність феохромоцитоми можна було орієнтовно судити на підставі даних двох великих серій автопсій: на 9285 автопсіях було знайдено $3(0,03 \%)$ пухлини [68] i серед 16394 - 7 (0,04\%) [69]. Більшість публікацій того періоду вміщували опис окремих випадків феохромоцитоми або невеликі серії клінічних спостережень, не більше за 8-10. Увага приділялася головним чином аналізу основних і рідкісних клінічних варіантів пухлин хромафінної тканини, ускладненням, питанням діагностики відповідно до можливостей того часу, техніки та безпечності оперативних втручань тощо. На цьому тлі важливою подією стала публікація 1965 року першої вітчизняної монографії О.В. Ніколаєва зі співавт. «Феохромоцитома» [65]. Власний досвід авторів, що був найбільшим в СРСР на той час, налічував 27 випадків пухлин хромафінної тканини, з них 17 успішних операцій. Поруч із нарисом анатомофізіологічних характеристик хромафінної тканини та похідних із неї пухлин було наведено сучасні дані про поширеність цієї патології, надзвичайно детально змальовано клінічну картину захворювання та варіанти клінічних синдромів, що його супроводжують, ускладнення, особливості перебігу у дітей, вагітних, у разі наявності злоякісних новоутворень, запропоновано оригінальну клінічну класифікацію. Велику увагу було приділено питанням діагностики та диференційної діагностики феохромоцитоми, підкреслено роль дослідження катехоламінів та їх метаболітів у крові та сечі й значення діагностичних функціональних проб. Серед методів топічної діагностики, поширених на той час, була оглядова рентгенографія з томографією або пієлографією. Провідне положення займали рентгенологічні газовоконтрастні методики пневморетроперитонеографії та пневморетроперинефрографії; зрідка використовували аортографію, венакаваграфію. Питання хірургічного лікування висвітлювалися на підставі власного, на той час значного, досвіду. До них належали передопераційна підготовка, вибір знеболювання та оперативних доступів, ведення операційного та поопераційного періодів, профілактика ускладнень. Невеликий розділ, присвячений феохромоцитомі, було вміщено у монографії професора О.В. Ніколаєва «Хірургія ендокринної системи», опублікованій 1952 року [66], а наступними роками у цій клініці продовжувалося інтенсивне вивчення проблем хромафінних пухлин. Його учнем К.Н. Казєєвим було успішно захищено першу кандидатську [70], а згодом докторську [71] дисертації, присвячені феохромоцитомі, в яких узагальнено досвід діагностики та лікування 120 хворих. Одночасно стало з'являтися дедалі більше публікацій, в яких, крім опису окремих випадків, наводилися відомості про хоч і невеликі, але власні серії спостережень феохромоцитоми. У літературі обговорювалися питання особливостей клініки, діагностики, хірургічного лікування, спадкові форми, синдром псевдофеохромоцитоми, злоякісні феохромоцитоми та пухлини у дітей, схеми профілактики та лікування ускладнень тощо. Наприклад, у серії праць В.В. Меньшикова розглядалися питання синтезу та обміну катехоламінів за феохромоцитоми, методи визначення та їх діагностичне значення. Кілька праць Г.Л. Ратнера присвячено симптоматичним гіпертензіям, у тому числі феохромоцитомі, механізмам їх розвитку, діагностичним підходам і методамлікування.Удеякімонографіїта керівництва включалися окремі розділи, присвячені пухлинам хромафінної тканини, де висвітлювалася ця проблема із сучасних позицій [67, 72-74]. Результати розробки науково-практичних проблем пухлин хромафінної тканини відображено у кількох дисертаціях [75-77].

Наступними десятиріччями в клініках, які займалися адреналовою хірургією, концентрувалися хворі 3 феохромоцитомою, впроваджувалися сучасні методики клініко-лабораторного та інструментальногообстеження (гормональнідослідження, УзД, КТ, МРТ тощо), схеми лікування. Почала поширюватися ендоскопічна хірургія надниркових залоз. На початок XX сторіччя деякі клініки мали досвід діагностики та лікування феохромоцитоми, що нараховував багато десятків і навіть кілька сотень 


\section{ЛЕКЦії}

спостережень, зокрема, клініка Московського інституту ендокринології - понад 800 [78], Московського обласного науково-дослідного клінічного інституту (МОНДКІ) - 244 [79].

В Україні початок вивчення та лікування пухлин хромафінної тканини припадає на 60-ті роки минулого сторіччя. У той час в клініці кафедри факультетської хірургії Львівського медичного інституту, керованої видатним українським хірургом професором Г.Г. Каравановим, було виконано перші операції з приводу феохромоцитоми. У подальшому, у міру накопичення досвіду, вивчалася клініка захворювання, запроваджувалися нові методи діагностики, вдосконалювалися техніка оперативних втручань, принципи знеболювання. 3 часів приходу до керівництва кафедрою професора, в майбутньому академіка М.П. Павловського, докторську дисертацію якого присвячено хірургічній патології кори надниркових залоз, адреналова хірургія стала одним $з$ основних напрямків діяльності клініки. 3 цих питань проводилися наукові дослідження, публікувалися численні статті, впроваджувалися методи ендоскопічних операцій на надниркових залозах і низка інших вдосконалень. Наразі досвід клініки у діагностиці та лікуванні феохромоцитоми перевищує 100 спостережень [80].

У Києві першу операцію з приводу феохромоцитоми виконано 1966 року в хірургічному відділі щойно створеного Інституту ендокринології та обміну речовин МЗ УРСР. Тут під керівництвом кандидата медичних наук, у майбутньому членкора АМН України, професора І.В. Комісаренка впродовж багатьох років розроблялися актуальні проблеми адреналової хірургії, зокрема феохромоцитоми. На кінець 90-х рр. у клініці було виконано понад 500 операцій із приводу феохромоцитоми. Крім детального вивчення клінічних і патофізіологічних характеристик пухлин хромафінної тканини, було розроблено ефективні схеми діагностики з використанням гормональних досліджень, функціональних проб. Окремо слід відзначити вдосконалення методів топічної діагностики. Було розроблено та впроваджено ангіографічні методики візуалізації пухлин надниркових залоз, зокрема селективної венографії, артеріографії, поєднані методики ангіографії з роздільним отриманням крові з кожної залози для визначення гормонів. Восьмидесятими роками вперше в Україні було застосовано методи ультразвукової сонографії для діагностики пухлин надниркових залоз, а згодом почали впроваджувати з цією метою комп'ютернута магнітно-резонансну томографію. Значною мірою було вдосконалено тактико-технічні принципи хірургічного лікування феохромоцитоми (передопераційна підготовка, знеболювання, доступи, технічні прийоми, обсяг операції, методики гемостазу, ведення інтра- та поопераційного періодів тощо). Слід також згадати дослідження функціонального стану інших залоз внутрішньої секреції у пацієнтів із феохромоцитомою, морфологічних характеристик пухлин, що сприяли повнішому розумінню особливостей клініки та перебігу захворювання. 3 усіх цих питань співробітниками клініки та лабораторій Інституту І.В. Комісаренком, Ю.В. Померанцевим, Т.П. Безверхою, В.М. Гордієнком, Л.А. Перепуст, О.Г. Югріновим, A.І. Шептухою, А.К. Чебаном, Г.В. Светловою, С.Й. Рибаковим та ін. опубліковано численні наукові праці, розділи у монографіях і керівництвах, інформаційні матеріали, зроблено доповіді на з'їздах і конференціях [81-84]. Співробітником клініки А.І. Шептухою 1979 року захищено першу в Україні дисертацію «Питання клініки, діагностики та хірургічного лікування пухлин хромафінної тканини» [85].

З 1994 р. інтенсивно на сучасному рівні вивчаються питання діагностики та лікування пухлин хромафінної тканини у створеному за ініціативою професора І.В. Комісаренка Українському науковопрактичному центрі ендокринної хірургії, трансплантації ендокринних органів і тканин МO3 України, де розвивається ендоскопічна хірургія надниркових залоз і накопичено найбільший у Східній Європі досвід лапароскопічних адреналектомій (понад 700 операцій). Серед них близько 100 успішних лапароскопічних операцій виконано професором С.М. Череньком із приводу феохромоцитом [86]. Нині операції з приводу феохромоцитом успішно виконуються також в Одесі, Харкові, Донецьку.

Завершуючи опис історії уявлень про пухлини хромафінної тканини, можна дещо умовно виділити декілька періодів розвитку цього процесу:

- період появи відомостей про феохромоцитому від 1886 р., коли її вперше було описано, до другої половини 20-х рр. XX сторіччя. У цей час накопичувалися дані про походження, структуру та функцію хромафінної тканини в організмі, синтез і метаболізм катехоламінів та їх участь у фізіологічних і патологічних процесах. Поодинокі пухлини хромафінної тканини виявлялися як казуїстичні знахідки на автопсії та ще не були об'єктами клінічної діагностики та лікування;

- період формування уявлень про феохромоцитому як окрему форму ендокринної патології, що 
охоплював час від перших випадків успішної діагностики та хірургічного лікування 1925-1927 роками до кінця 50-х рр. У цей час вивчалися клінічні характеристики, особливості перебігу, ускладнення, патофізіологічні механізми розвитку варіантів артеріальної гіпертензії та інших клінічних синдромів, що супроводжують феохромоцитому. Особлива увага приділялася визначенню ролі катехоламінів, що стало можливим завдяки з'ясуванню їх ролі у патогенезі. Надзвичайну роль для діагностики відіграла розробка методів кількісного визначення вмісту катехоламінів та їх метаболітів у біологічних середовищах організму та пневморентгенологічних методів візуалізації надниркових залоз, впровадження функціональних проб. Одночасно формувалися уявлення про епідеміологічні характеристики феохромоцитоми на підставі аналізу збірних статистик. Хірургічне лікування ще не набуло системного характеру, але з'являлося дедалі більше повідомлень про успішне лікування невеликих кількостей хворих;

- період з 60-х до початку 80-х рр. відзначався продовженням цілеспрямованих досліджень, що починалися у попередні часи, та характеризувався створенням ефективних системних схем діагностики та хірургічного лікування пухлин хромафінної тканини. Поглиблене вивчення патогенезу дії катехоламінів, ролі a- та $\beta$-рецепторів, синтез низки препаратів - блокаторів дії катехоламінів дозволили значно поліпшити результати лікування, надто в аспекті безпечності оперативних втручань і профілактики ускладнень. Поява нових методів топічної діагностики (УЗД, КТ, МРТ) дала можливість виявлення пухлин вкрай малих розмірів. Паралельно було значно вдосконалено тактико-технічні підходи до лікування феохромоцитоми, що стосувалися питань знеболювання, технічних прийомів операцій, ведення інтра- та поопераційного періодів тощо;

- час із початку 80-х рр. відзначається продовженим поглибленим аналізом перерахованих вище питань стосовно феохромоцитоми, накопиченням великих обсягів клінічного матеріалу в багатьох спеціалізованих клініках, переходом до вивчення молекулярно-генетичних особливостей цієї патології, питань канцерогенезу. Цей період відзначається подальшим удосконаленням методів діагностики та впровадженням нових технологій (ендоскопічна хірургія, роботизовані операції), створенням сучасних алгоритмів діагностики та лікування феохромоцитоми.

\section{ЛITEPATУPA}

1. DeCourcy J., DeCourcy L. Pheochromocytomas and the General Practitioner. - Cincinati: Barclay Newman, 1952. - 163 p.

2. Aranov W. Pheochromocytoma // In: Bean W. (ed.) Monographs in Medicine. Series 1. Baltimore: Williams and Willkins, 1952. - P. 179-224.

3. Robinson R. Tumours that secrete catecholamines: Their detection and clinical chemistry. - Chichester: John Willey and Sons, 1980. - P. 1-65.

4. Frankel F. Ein Fall von doppelseitigem, völlig latent verlaufenen Nebennierentumor und gleichzleitizer Nephritis mit Veronderungen am Circulationsappararat und Retinitis // Virchows Arch. Pathol. Anat. Physiol. Klin. Med. - 1886. - Vol. 103. - P. 244-263.

5. Berdez Contribution a l'etude des tumerirs des capsule surrenales // Arch. Med. Exp. (Paris). - 1892. Vol. 4. - P. 412-415.

6. Manasse $P$. Über die hyperplasttischen Tumoren der Nebennieren // Virchows Arch. Pathol. Anat. - 1893. Vol. 133. - P. 391-404.

7. Manasse P. Zur Histologie und Histogenese der primaren Nierengeschwülste // Virchows Arch. Pathol. Anat. - 1896. - Vol. 145. - P. 113-157.

8. Alezais $H_{\text {., }}$ Peyron F. Un groupe nouveau tumeurs epitheliales: les paraganglions // C.R. Seances Soc. Biol. Paris. - 1908. - Vol. 65. - P. 745-747.

9. Pick L. Das Ganglioma embrionale sympathicum (Sympatoma embrionale) eine tipische bösartige geschwuestform des sympathischen nervensystems // Berl. Klin. Wochenschr. - 1912. - Vol. 49. - P. 16-22.

10. L'Abbe M., Tinel J., Doumer E. Crises solaires et hypertension paroxystique en rapport avec une tumeur surrenale // Bull. Soc. Med. Hop. (Paris). 1922. - Vol. 46. - P. 982-990.

11. Masson P., Martin J. Paragangliome surrenale // Bull. Assoc. Fr. Cancer. - 1923. - Vol. 12. - P. 135-143.

12. Müchl von der $R$. Contribution e l'etude des paragangliomes. - Lausanne: L'Universite de Lausanne. Thesis. - 1928. - 32 p.

13. Mayo Ch. Paroxysmal hypertension with tumor of retroperitoneal nerve. Report of a case // JAMA. - 1927. - Vol. 89. - P. 1047-1050.

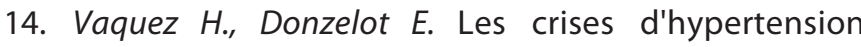
arterielle paroxystique // Presse Med. - 1926. - Vol. 34 - P. 1329-1331.

15. Pincoff M. A case of paroxysmal hypertension associated with suprarenal tumor // Trans. Assoc. Am. Physicians. - 1929. - Vol. 44. - P. 295-299.

16. Shipley A. Paroxysmal hypertension associated with tumor of the suprarenal // Ann. Surg. - 1929. - Vol. 90 - P. 742-74.

17. Rollestone $H$. The endocrine organs in health and disease, with an historical review. - Oxford: Oxford University Press; London: Humphrey Milford, 1936. $521 \mathrm{p}$.

18. Carmichael S. The adrenal medulla, Vol. 4. - New York: Cambrige Unsversity Press, 1986. - 259 p.

19. Rabin C. Chromaffin cell tumor of the suprarenal medulla (Pheochromocytoma) // Arch. Pathol. (Chicago). - 1929. - Vol. 7. - P. 228-243. 
20. Kelly H., Piper M., Wilder R. et al. Case of paroxysmal hypertension with paraganglioma of the right suprarenal gland // Mayo Clin. Proc. - 1936. - Vol. 11. P. 65-70.

21. Beer E., King F., Prinzmetal M. Pheochromocytoma with demonstration of pressor (adrenalin) substance in blood preoperatively during hypertensive crises // Ann. Surg. - 1937. - Vol. 106. - P. 85-91.

22. Strömbeck J., Hedberg T. Tumor of the suprarenal medulla associated with paroxysmal hypertension. Report of case preoperatively diagnosed and cured by extirpation after capsular incision // Acta Chir. Scand. 1939. - Vol. 82. - P. 177-189.

23. Paul F. Die krankhafte function der nebenniere ihr gestaltlicher ausdruck // Virchows Arch. Pathol. Anat. Klin Med. - 1931. - Vol. 282. - P. 256-326.

24. van Goidsenhoven F., Appelmans R. Contribution e l'etude clinique et therapeutique de l'hypertension paroxystique // Bull. Acad. Royal Med. Belge. - 1934. P. 672-674.

25. Holton $P$. Noradrenaline in tumours of the adrenal medulla // J. Physiol. (London). - 1949. - Vol. 108. - P. 525-529.

26. von Euler U. Noradrenaline. - Springfield, III: C. C. Thomas, 1956. - $382 \mathrm{p}$.

27. von Euler U., Ström G. Present status of diagnosis and treatment of pheochromocytoma // Circulation. - 1957. - Vol. 15. - P. 5-13.

28. Lund A. Adrenaline and noradrenaline in blood and urine in cases of pheochromocytoma // Scand. J. Clin. Lab. Invest. - 1952. - Vol. 4. - P. 263-265.

29. Montgomery D. Wellbourn R. Medical and surgical endocrinology. - London: Edward Arnold, 1975. 599 p.

30. Engelman K., Sjoerdesma A. A new test for pheochromocytoma: Pressor responsivness to tiramine // J. Am. Med. Ass. - 1964. - Vol. 189. - P. 81-86.

31. Manger W., Gifford R., Hoffman B. Pheochromocytoma: A clinical and experimental overview // Curr. Probl. Cancer. - 1985. - Vol. 9. - P. 1-89.

32. MacKenzie D., McEachern D. Adrenal pheochromocytoma // Trans. Am. Assoc. Genito-urinary Surgeons. - 1938. - Vol. 31. - P. 127-160.

33. Brunschwig A., Humphreys E. Excision of pheochromocytoma // JAMA. - 1940. - Vol. 115. - P. 355-357.

34. Binger M., Craig W. An atypical case of hypertension with a tumor of the adrenal gland // Mayo. Clin. Proc. - 1938. - Vol. 13. - P. 17-20.

35. Mackeith R. Adrenal-sympathetic syndrome: chromaffin tissue tumor with paroxysmal hypertension // Br. Heart. J. - 1944. - Vol. 6. - P. 1-12.

36. Calkins E., Howard J. Bilateral familial pheochromocytoma with paroxysmal hypertension: successful removal of tumors in two cases, with discussion on certain diagnostic procedures and physiological considerations // J. Clin. Endocrinol. - 1947. - Vol. 7. - P. 475-492.

37. Roth G., Kvale W. A tentative test for pheochromocytoma // Am. J. Med. Sci. - 1945. - Vol. 210. - P. 653-660.
38. Goldenberg M., Snyder C., Aranow H. New test for hypertension due to circulating epinephrine // JAMA. - 1947. - Vol. 135. - P. 971-976.

39 Ganem E., Cahill G. Pheochromocytoma coexisting in adrenal gland and retroperitoneal. Space with sustained hypertension // New Engl. J. Med. - 1948. - Vol. 238. - P. 692-697.

40. Iseri L., Henderson H., Derr J. Use of adrenolitic drug Regitine in pheochromocytoma // Am. Heart. J. - 1952. - Vol. 42. - P. 129-136.

41. Graham J. Pheochromocytoma and hypertension. An analysis of 207 cases // Int. Abst. Surg. - 1951. - Vol. 92. - P. 105-121.

42. Kwale W., Roth G., Manger W. Pheochromocytoma // Circulation. - 1956. - Vol. 14. - P. 622-630.

43. Minno A., Bennet W., Kwale W. Pheochromocytova. A study of 15 cases diagnosed et autopsy // New Engl. J. Med. - 1954. - Vol. 251. - P. 959-965.

44. Barbeau A. Le pheochromocytome: Une revue generale du sujet // Union Med. Can. - 1957. - Vol. 86. P. 1045-1081.

45. Hume D. Pheochromocytoma in the adult and in the child // Am. J. Surg. - 1960. - Vol. 99. - P. 458-496.

46. Brunjes S., Johns V., Crane M. Pheochromocytoma: postoperative shock and blood volume // New Engl. J. Med. - 1960. - Vol. 262. - P. 393-396.

47. Hyman A., Mencher W. Pheochromocytoma of the adrenal gland // J. Urol. - 1943. - Vol. 49. - P. 755-771.

48. Cushman P. Familial endocrine tumors // Am. J. Med. 1962. - Vol. 32. - P. 352-360.

49. Sipple J. The association of pheochromocytoma with the carcinoma of the thyroid gland // Am. J. Med. 1961. - Vol. 31. - P. 163-166.

50. Eisenberg A., Wallerstein H. Pheochromocytoma of the suprarenal medulla (paraganglioma) // Arch. Pathol. Lab. Med. - 1932. - Vol. 14. - P. 818-836.

51. Steiner A., Goodman A., Powers S. Study of kindred with pheochromocytoma, medullary thyroid carcinoma, hyperparathyroidism and Cushing's disease: Multiple endocrine neoplasia type 2 // Medicine (Baltimore). 1968. - Vol. 47. - P. 371-409.

52. Chong G., Beahrs O. Sizemore G. et al. Medullary carcinoma of the thyroid gland // Cancer. - 1975. Vol. 35. - P. 695-704.

53. Schimke R., Hartmann W., Prout T. et al. Syndrome of bilateral pheochromocytoma. medullary thyroid carcinoma and multiple neuromas. A possible regulatory defect in the differentiation of chromaffin tissue // New Engl. J. Med. - 1968. - Vol. 279. - P. 1-7.

54. Zimmerman I., Biron R., MacMahon H. Pheochromocytoma of the urinary bladder // New Engl. J. Med. - 1953. - Vol. 249. - P. 25-26.

55. Khan O., Williams G., Chisholm G. et al. Pheochromocytoma of the bladder // J. Royal Soc. Med. - 1982. - Vol. 75. - P. 17-20.

56. Glenner G., Crout G., Roberts W. A noradrenalinesecreting carotid-body-like tumor // Lancet. - 1961. N. 2. - P. 439.

57. Lawrence A. A new provocative test for pheochro- 
mocytoma // Ann. Int. Med. - 1965. - Vol. 63. P. 905-906.

58. Sisson J., Frager M., Valk T. et al. Scintigraphic localization of pheochromocytoma // New Engl. J. Med. - 1981. Vol. 305. - P. 12-17.

59. Gagner M., Lacroix A., Bolte E. Laparoscopic adrenalectomy in Cushing's syndrome and pheochromocytoma // New Engl. J. Med. - 1992. - Vol. 327. - P. 1033.

60. Брюханов Н.И. О первичных опухолях надпочечников: Дисс. - СПб., 1899. - 50 с.

61. Крылов А.А. К казуистике первичных опухолей мозгового слоя надпочечной железы // Казанский мед. журнал. - 1929. - № 6. - С. 627-631.

62. Журавлева В.И. К вопросу о так называемых симпатогониомах и хромаффиномах надпочечников // Сб. Работ Казанского мед. института. - Казань, 1931. - № 1. - С. 54-56.

63. Аничков Н.Н. О злокачественных нейромах (нейробластомах) симпатической системы // Нов. хир. архив. - 1924. - № 27. - С. 335-342.

64. Бец В.А. Анатомические и гистологические исследования. Избранные труды. - М.: Медгиз, 1950. - 299 с.

65. Николаев О.В., Меньшиков В.В., Калинин А.П. и др. Феохромоцитома. - М.: Медицина, 1965. - 233 с.

66. Николаев О.В. Хирургия эндокринной системы. - М.: 1952. - $192 \mathrm{c}$.

67. Ратнер Г.Л., Чернышев В.Н. Лечение симптоматических гипертоний. - М.: Медицина, 1973. - 174 с.

68. Брискин Б.С., Кронрод Б.А. Метастазирующие феохромобластомы // Вестник хирургии им. И.И. Грекова. - 1962. - № 6. - С. 94-96.

69. Домбровская Е.А. О феохромоцитомах и феохромобластомах // Урология. - 1962. - № 5. - С. 51-55.

70. Казеев К.Н. Клиника, диагностика и хирургическое лечение феохромоцитомы: Автореф. дисс ... канд. мед. наук. - М., 1966.

71. Казеев К.Н. Доброкачественные и злокачественные опухоли хромаффинной ткани. Хирургическое лечение и отдаленные результаты: Автореф. дисс. ... д-ра. мед. наук. - М., 1974. - 36 с.

72. Милославский Я.М., Меньшиков В.В., Большакова Т.Д. Надпочечники и артериальная гипертония. - М.: Медицина, 1971. - 259 с.

73. Калинин А.П., Калюжный И.Т., Нурманбетов Д.Н. Неотложная эндокринология. - Фрунзе: Илим, 1989. $-351 \mathrm{c}$.

74. Торгунаков А.П. Псевдофеохромоцитома. - Кемерово: Кемеровское книжное издательство, 1990. $-190 \mathrm{c}$.

75. Муромцев Ю.В. Особенности и коррекция операционной патологии при хирургическом лечении феохромоцитомы: Автореф. дисс. ... канд. мед. наук. - М., 1966.

76. Хмельницкий Г.А. Морфологические характеристики феохромоцитомы: Автореф. дисс. ... канд. мед. наук. - Л., 1974.

77. Кипиани К.Б. Диагностика и хирургическое лечение больных феохромоцитомой: Автореф. дисс. ... канд. мед. наук. - М., 1975.
78. Дедов И.И., Бельчевич Д.Г., Кузнечов Н.С. Феохромоцитома. - М.: Практическая медицина, 2005. - 218 с.

79. Калинин А.П., Полякова Г.А., Шумский В.И. Подходы и стандартизация клинико-морфологического исследования катехоламин-секретирующих опухолей надпочечников // Современные аспекты хирургического лечения эндокринной патологии. Материалы Первого Украинско-Российского симпозиума по эндокринной хирургии, Киев, 13-14 октября 2006 г.: К., 2006. - C. 113-115.

80. Бойко Н.І., Довгань Ю.П., Павловський М.П. Результати хірургічного лікування хворих з пухлинами надниркових залоз // Современные аспекты хирургического лечения эндокринной патологии. Материалы Первого Украинско-Российского симпозиума по эндокринной хирургии, Киев, 13-14 октября 2006 г.: K., 2006. - C. 124-125.

81. Перепуст Л.А. Рентгенодиагностика опухолей надпочечников. - М.: Медицина, 1972. - 214 с.

82. Ефимов А.С., Комиссаренко И.В., Скробонская Н.А. Неотложная эндокринология. - М.: Медицина, 1982. -207 c.

83. Комиссаренко И.В., Безверхая Т.П., Беникова Е.А. и др. Нарушение функции надпочечников при эндокринных заболеваниях. - К.: Здоров'я, 1984. - 235 с.

84. Югринов О.Г. Ангиография и рентгенэндоваскулярная хирургия при заболеваниях надпочечников: Автореф. дисс. ... д-ра. мед. наук. - К., 1990. - 40 с.

85. Шептуха А.И. Вопросы клиники, диагностики и лечения опухолей хромаффинной ткани: Дисс. ... канд. мед. наук. - К., 1979. - 196 с.

86. Черенько С.М., Ларин А.С., Товкай А.А. Итоги десятилетнего опыта лапароскопических адреналэктомий //Сучасні медичні технології. - 2013. - №3 (19). - C. 217-219.

\section{PEЗЮME \\ До історії феохромоцитоми С.Й. Рибаков}

У лекції описано історію розвитку уявлень про одне $з$ найскладніших і найтяжчих захворювань надниркових залоз - феохромоцитому. Наведено світовий досвід від перших випадкових операцій до створення сучасних систем діагностики та лікування цієї патології. Підкреслено значення діагностичних підходів, зокрема визначення катехоламінів, та їх роль у патогенезі захворювання. Відзначено, що розробка методів безпечних оперативних втручань, знеболення та інтенсивної терапії забезпечила значне поліпшення результатів лікування. Висвітлено роль вітчизняних дослідників у розробці проблем пухлин хромафінної тканини.

Ключові слова: феохромоцитома, патогенез, діагностика, лікування. 


\section{PEЗЮME}

\section{К истории феохромоцитомы}

\section{С.И. Рыбаков}

В лекции описана история развития представлений об одном из наиболее сложных и тяжелых заболеваний надпочечников - феохромоцитоме. Представлен мировой опыт от первых случайных операций до создания современных систем диагностики и лечения этой патологии. Подчеркнуты значение диагностических подходов, в частности определения катехоламинов, и их роль в патогенезе заболевания. Отмечено, что разработка методов безопасных оперативных вмешательств, обезболивания и интенсивной терапии обеспечила значительное улучшение результатов лечения. Освещена роль отечественных исследователей в разработке проблем опухолей хромаффинной ткани.

Ключевые слова: феохромоцитома, патогенез, диагностика, лечение.

\section{SUMMARY \\ To history of pheochromocytoma \\ S. Rybakov}

The history of tumors, which is derived from chromaffin tissue of adrenal glands - pheochromocytoma, is described from the end of XIX century to the present days. It begins from the first cases of these tumors which were founded at autopsies or at a few operations to a wide screen investigation of epidemiology, clinical characteristics, pathogenesis of pheochromocytoma. The role of adrenal hormones (epinephrine and norepinephrine) in pathogenesis and diagnostic procedure in pheochromocytoma is mentioned. Special attention is given to the description of modern methods of diagnosis and surgical treatment. The role of scientist of our country in development of knowledge about pheochromocytoma is mentioned. The main chronological periods of data about pheochromocytoma are characterized.

Key words: pheochromocytoma, pathogenesis, diagnostic, treatment. 